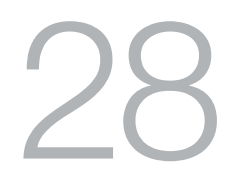

\title{
Rainbow Labor and a Purple Policy Launch: Gender and Sexuality Issues
}

\section{Blair Williams and Marian Sawer}

In 2016, the Coalition's proposed plebiscite on same-sex marriage became a significant issue in the election and there was also a record number of openly gay candidates. For the first time, Labor had a rainbow policy launch, targeted at the lesbian, gay, bisexual, trans and intersex (LGBTI) community. The Coalition lacked a similar policy launch or formal rainbow network, but increased its number of openly gay parliamentarians and overtook Labor in terms of LGBTI representation.

The rise in salience of LGBTI issues was not matched by similar attention to gender equality, despite bipartisan agreement on a number of issues such as domestic violence. When Labor had a women's policy launch and put forward significant machinery of government and other commitments, these failed to attract media attention. One of the few gender equality issues to gain traction was the fact that the number of women on the Coalition side in the House of Representatives was clearly going to fall. In Australia, there has been a notable lack of 'contagion' of women candidates across the party spectrum and the partisan gender gap in the House of Representatives has never been wider. 


\section{The campaign}

Most remarkable during this election campaign were the declarations of feminism from male leaders on both sides of politics. Labor Leader Bill Shorten had already signalled in his Budget Reply speech the priority a new Labor government would give to 'equality for women', including closing the gender pay gap, properly funding childcare and paid maternity leave and bringing more women into parliament and cabinet (Shorten 2016a). It was 'closing the gender pay gap' that brought most applause-currently, the average gender pay gap for full-time workers is 17.3 per cent (Workplace Gender Equality Agency 2016). Shorten continued to emphasise equality for women throughout the campaign; even Labor's policy speech began with the salutation 'Women and Men of Australia' in that order.

Nonetheless, during the campaign, Shorten triggered a 'feminism debate' through remarks described by Nationals Deputy Leader Fiona Nash as 'disgraceful and prehistoric' and by television host Lisa Wilkinson as 'dinosaur views'. When talking about Labor's $\$ 3$ billion childcare package, Shorten had said that the package would assist women's workforce participation and, 'let's face it, men in Australia rely on the women in Australia to do the childcare and to organise child care' (Koziol 2016a; Reynolds and Schipp 2016). Shorten strongly defended his remarks, saying that it was clear that the burden of childcare still fell disproportionately on 'working mums', and this needed to be addressed (Beech 2016a).

In turn, Prime Minister Malcolm Turnbull was asked whether he considered himself to be a feminist, to which he replied: 'I am a feminist, yes ... [women are] taking the world by storm' (Cox 2016a). In contrast, both Liberal Deputy Leader Julie Bishop and Minister for Women Michaelia Cash were reluctant to identify as feminists. This is an ongoing theme-conservative men announcing their feminism whilst their women colleagues reject the label. The ' $f$ ' word appears too controversial for women to own, and yet outdated and antiwomen for men not to. Conservative men are able to claim the 'f' word to help with their 'women problem', yet women may be seen as 'man-hating' or 'lesbians' if they do. Research across 10 European countries has confirmed that in both centre-right (liberal and conservative) and far-right parties, men are more likely than women to identify as promoting gender equality, suggesting it is riskier for women than men to do so (Celis and Erzeel 2015: 55-56). 


\section{Candidates}

While for the first time all four leading political parties, including the Nationals, had women deputy leaders at this election, there was a notable shortage of Liberal women candidates. This was despite the Liberal Party's commitment to a target of 50 per cent female candidates by 2025 (Liberal Party of Australia (LPA) 2016) and the fact that with a self-described 'feminist' leader, the Liberal Party was expected to do more for gender balance than under Tony Abbott's leadership. Thanks to the Coalition, Australia has continued to slide down the international league table on representation of women in national parliaments and, on 1 July 2017, was in 50th place (Inter-Parliamentary Union (IPU) 2017).

It is clear that on the issue of women candidates there has been a lack of 'contagion' within the party system. Early studies of party quotas suggested that once one party had introduced them, rival parties were likely to follow suit thanks to the dynamics of party competition. The contagion of women candidates was thought particularly likely to occur within systems of proportional representation, with Norway being one subject of an influential early study (Matland and Studlar 1996). It has now been found that while such diffusion has occurred in countries such as Sweden or Spain, in others such as Iceland and Portugal contagion across the party system has been low or moderate (Kenny and Verge 2013: 18).

This is definitely the case in Australia: the introduction of an effective candidate quota by the Labor Party in 1994 has so far failed to diffuse across the political spectrum. The surge of Liberal women into the House of Representatives in 1996, with the help of a mentoring program set up by the Liberal Women's Forum, was not maintained. There has been an absence on the Coalition side of an effective ginger group, like the Laboraligned EMILY's List, to maintain pressure on the party over preselections and policy. In 2016, the proportion of women among Coalition MPs fell to 17 per cent, its lowest point since 1993 (Figure 28.1). Similar trends have occurred at the State level, with dramatic falls in the number of women on the government benches when the Coalition has won office in recent elections. 


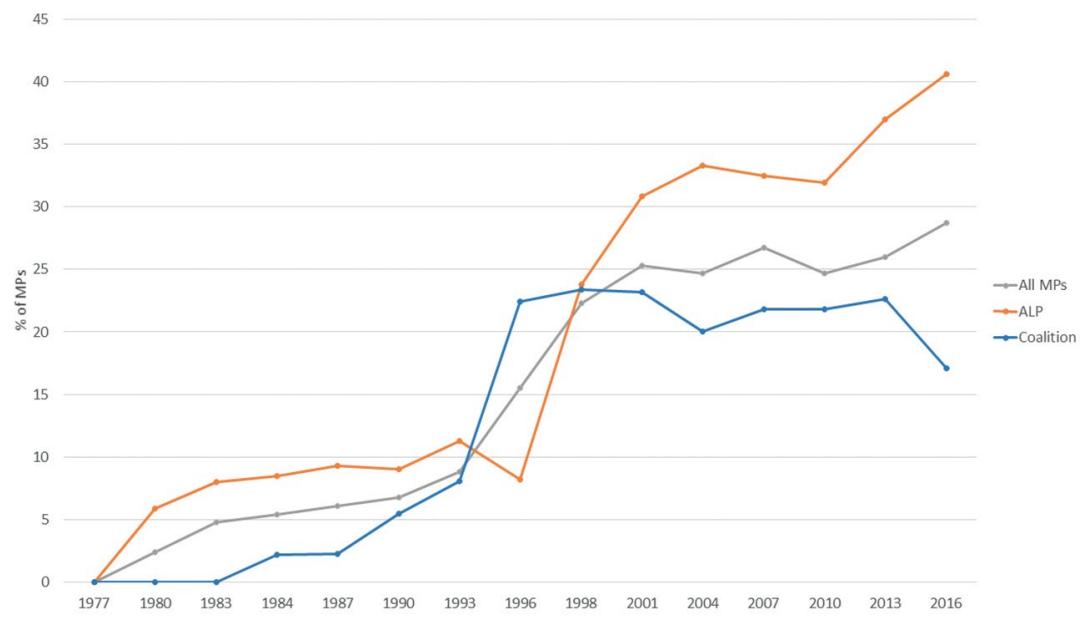

Figure 28.1. Women as a percentage of Coalition and Labor MPs in the House of Representatives, 1977-2016

Source. Compiled by Marian Sawer, based on Parliamentary Library figures.

Although the proportion of women in the House of Representatives rose slightly in 2016 (from 26.7 per cent to 28.7 per cent), most of these women were on the opposition benches (Table 28.1). Interestingly, in around half of the seats won by women the contest was ultimately between two women and 16 of the seats retained by women had a female challenger from either Labor or the Coalition.

Table 28.1. Gender breakdown of the House of Representatives after the 2016 election

\begin{tabular}{|l|r|r|r|}
\hline Party & \multicolumn{1}{|c|}{ Male } & Female & $\begin{array}{c}\text { Female } \\
\text { (percentage) }\end{array}$ \\
\hline Labor & 41 & 28 & 40.6 \\
\hline Coalition & 63 & 13 & 17.1 \\
\hline Greens & 1 & 0 & 0 \\
\hline Nick Xenophon Team & 0 & 1 & 100 \\
\hline Katter's Australian Party & 1 & 0 & 0 \\
\hline Independents & 1 & 1 & 50 \\
\hline Total & 107 & 43 & 28.7 \\
\hline
\end{tabular}

Source. Compiled by Marian Sawer, based on Parliamentary Library figures. 
Even in the Senate with proportional representation, an electoral system generally more favourable to women's representation, women made up only 27 per cent of Coalition Senators after the 1996 election-compared with 54 per cent of Labor Senators and 56 per cent of Greens Senators (Table 28.2). The gender difference between the major parties was dramatically illustrated by the Tasmanian Senate result - an all-female team of five Labor Senators was returned as contrasted with an all-male Liberal team of four. Despite the efforts of several Liberal women parliamentarians to instigate change (e.g. Troeth 2010), the Coalition has continued to maintain that the adoption of quotas would 'patronise' women. During the campaign, Vote Compass found that while a majority of Labor voters backed quotas, 60 per cent of Coalition voters opposed them. Overall, men were almost twice as likely as women to oppose quotas (Australian Broadcasting Corporation 2016).

Table 28.2. Gender breakdown of the Senate after the 2016 election

\begin{tabular}{|l|r|r|r|}
\hline Party & \multicolumn{1}{|c|}{ Male } & Female & $\begin{array}{c}\text { Female } \\
\text { (Percentage) }\end{array}$ \\
\hline Labor & 12 & 14 & 54 \\
\hline Coalition & 22 & 8 & 27 \\
\hline Greens & 4 & 5 & 56 \\
\hline Nick Xenophon Team & 2 & 1 & 33 \\
\hline Pauline Hanson's One Nation & 3 & 1 & 25 \\
\hline Derryn Hinch's Justice Party & 1 & 0 & 0 \\
\hline Family First Party & 1 & 0 & 0 \\
\hline Jacqui Lambie Network & 0 & 1 & 100 \\
\hline Liberal Democratic Party & 1 & 0 & 0 \\
\hline Total & 46 & 30 & 39.5 \\
\hline
\end{tabular}

Source. Compiled by Marian Sawer, based on Parliamentary Library figures.

Despite there being fewer Liberal women in the House of Representatives, the number of women in the Cabinet remained at six. This was a vast improvement on Abbott's 2013 Cabinet (see Table 28.3) where there was only one woman, Julie Bishop. It is notable, however, that not only was the proportion of women in Cabinet (26 per cent) considerably less than the proportion of women in the Labor Shadow Cabinet (35 per cent), but half the women in the Turnbull Cabinet were childless, compared with none of the women in the Labor Shadow Cabinet. This perhaps indicates 
the greater difficulty women with children have in rising through Coalition ranks. All the men in the Turnbull Cabinet had children, indicating that for men, unlike women, children are a political advantage.

Table 28.3. Gender breakdown of Cabinet, 2010-16

\begin{tabular}{|l|r|r|r|}
\hline Cabinet & \multicolumn{1}{|c|}{ Male } & Female & $\begin{array}{c}\text { Female } \\
\text { (Percentage) }\end{array}$ \\
\hline Gillard August 2010-13 & 16 & 4 & 20.0 \\
\hline Rudd 2013 & 14 & 6 & 30.0 \\
\hline Abbott 2013-15 & 18 & 1 & 5.2 \\
\hline Turnbull Sept-December 2015 & 16 & 5 & 23.8 \\
\hline Turnbull July 2016 & 17 & 6 & 26.1 \\
\hline
\end{tabular}

Source. Compiled by Blair Williams based on Parliamentary Library figures.

While the numbers of Coalition women in the House of Representatives decreased, the number of gay Coalition politicians has increased. Overall, according to Australian Marriage Equality, there was a record number of LGBTI candidates standing in the 2016 election-23 for the Greens, seven for Labor, six for the Liberals and 'at least six from minor parties or Independents' (Karp 2016). After the election, the Coalition had four openly gay parliamentarians compared with Labor's three (see Tables 28.4 and 28.5). This is a remarkable development that has taken place quite suddenly since Western Australian Senator Dean Smith was first elected in 2012. Smith was followed in 2015 by Trent Zimmerman, the first openly gay man to be elected to the House of Representatives. In 2016, these two were joined by Tim Wilson, in the safe Liberal seat of Goldstein, and by Trevor Evans in the seat of Brisbane, where Labor had also stood a gay candidate.

Notable gay Coalition candidates who were not successful included Jonathan Pavetto in Bob Katter's Queensland seat of Kennedy (the seat Katter had claimed contained no homosexuals) and Aboriginal man Geoffrey Winters in Labor Deputy Leader Tanya Plibersek's seat of Sydney.

On the Labor side, Louise Pratt, National Co-Convenor of Rainbow Labor, regained a Senate seat after defeat in the 2014 rerun of the Western Australian Senate election, Senator Penny Wong continued in her leadership role as Labor Senate Leader and Julian Hill was elected to the seat of Bruce. Following the election, the Queensland State Conference of the party adopted a 5 per cent quota for LGBTI candidates in winnable seats at State, federal and local government levels, the first LGBTI quota in Australia. 
In the Greens, Robert Simms, party spokesperson on Sexual Orientation, Gender Identity and Intersex, lost his South Australian Senate seat, but Janet Rice retained her Victorian Senate seat. Hence, LGBTI representation in the Senate was at 5 per cent and in the House of Representatives 3 per cent (Tables 28.4 and 28.5). In the UK House of Commons, LGBTI representation reached 5 per cent after the 2015 general election (32 out of 650 MPs) and 6.9 per cent after the 2017 election.

Table 28.4. LGBTI representation in the House of Representatives after the 2016 election

\begin{tabular}{|l|r|r|}
\hline Party & Male & Female \\
\hline Labor & 1 & 0 \\
\hline Coalition & 3 & 0 \\
\hline
\end{tabular}

Source. Compiled by Marian Sawer.

Table 28.5. LGBTI representation in the Senate after the 2016 election

\begin{tabular}{|l|r|r|}
\hline Party & Male & Female \\
\hline Labor & 0 & 2 \\
\hline Coalition & 1 & 0 \\
\hline Greens & 0 & 1 \\
\hline
\end{tabular}

Source. Compiled by Marian Sawer.

\section{Sexuality policies}

One of the big issues of the election was the debate over same-sex marriage. Despite the number of openly gay Coalition candidates, the Coalition's sexuality policies were dogged by a commitment to hold a plebiscite on same-sex marriage. This commitment was a delaying tactic in regards to marriage equality dating from the Abbott leadership. While it was not a tactic that had been supported by Turnbull, it was part of the price extracted by the conservative wing of the Liberal Party and the Nationals for their support. There was not only the commitment to a plebiscite, which Labor repeatedly labelled a 'taxpayer-funded platform for homophobia', but also the uncertainty about whether conservative members of the Coalition would vote for same-sex marriage regardless of the outcome of the plebiscite. 
This issue bubbled away, with speculation about whether Coalition parliamentarians would vote in accordance with the outcome of the plebiscite, the outcome in their own electorate or with their own conscience. South Australian Greens Senator Robert Simms, who is openly gay, asked how the Prime Minister could justify spending ' $\$ 160$ million on what was in effect a giant opinion poll not even binding on his own members' (Knott 2016). Another issue for the Coalition was the opposition within its ranks to the Safe Schools program directed against homophobia and bullying in schools. When a mass shooting occurred during the election campaign at a gay nightclub in Orlando, Florida, Prime Minister Turnbull initially failed to respond to its homophobic dimension, describing it only as an assault on 'freedom'. However, while he did not go as far as Labor in expressing solidarity with the LGBTI community over the shooting, he did subsequently describe it as a 'murderous attack on gay people' (Koziol 2016b). Unsurprisingly, given the divisions between conservatives and moderates in its ranks, the Coalition did not release a policy document targeted at the LGBTI community, unlike Labor and the Greens. The Coalition Co-Chair of the Parliamentary Friends of LGBTIQ Australians also believed it unlikely that the Coalition would develop such a policy in the future. ${ }^{1}$

Similarly, in the UK general election in 2015, the Conservatives did not release a separate manifesto directed at the LGBTI community, unlike Labour, the Liberal Democrats and the Greens. However, unlike the Coalition in Australia, the UK Conservatives did include a number of LGBTI-related pledges in their general manifesto, such as tackling 'homophobic, bi-phobic and transphobic bullying' in schools. The Scottish National Party pledged in its manifesto to support the creation of an LGBTI-rights envoy in the Foreign Office, 'to promote the rights of LGBTI people throughout the world, as an integral part of UK foreign policy' (Smith 2015).

In Australia, Labor (and the Greens) had straightforward commitments both on marriage equality and discrimination against the LGBTI community, although the Greens went further in terms of wanting to end the religious exemption in Australia's antidiscrimination laws. Shorten was praised as a 'champion of the LGBTI community' (Power 2016) and, in another development, the large Shop, Distributive

1 Interview with Warren Entsch MP, 1 December 2016, Parliament House, Canberra. 
and Allied Employees Association, which effectively controls a number of Labor preselections, had finally dropped its opposition to marriage equality. Vote Compass found a majority of Australians (or at least a majority amongst its 350,000 respondents) supported marriage equality, with support particularly strong among young people and women (Blumer 2016). However, while this seems to align with Labor and Green positions, polls during the campaign indicated a majority of Australians also favoured 'having a say' in a plebiscite. This was to change after the election as the full implications of the plebiscite proposal became clearer.

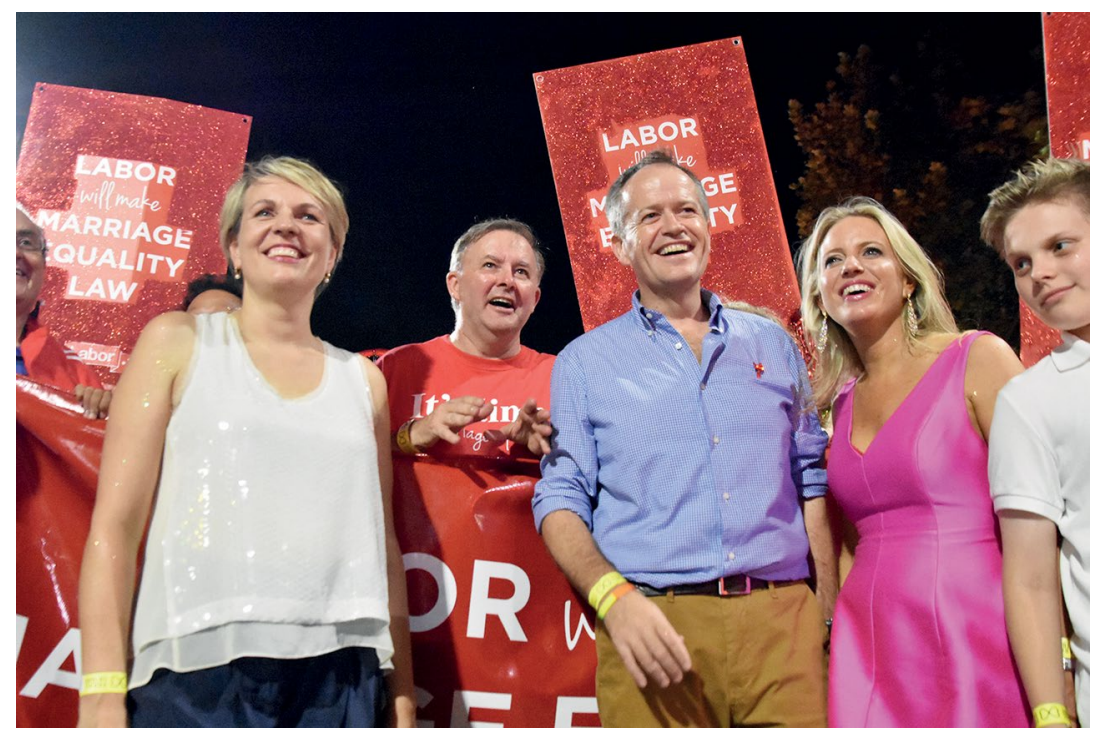

Figure 28.2. Rainbow Labor, 2016 Mardi Gras

Source. Photographed by OAnn-Marie Calilhanna, Mardi Gras, Sydney, 24 June 2016. Used with permission.

For the first time, in 2016 Labor included a Rainbow Labor campaign launch in its federal election campaign. The length of the campaign made it easier to fit such a launch into the campaign's early stages and it provided an opportunity to showcase popular policies. ${ }^{2}$ Rainbow Labor has become a flourishing network within the party and has been successful in changing Labor policy on marriage equality. It is differently situated in

2 Interviews were conducted with Senator Louise Pratt (1 September 2017, Parliament House, Canberra); the Hon. Penny Sharpe MLC (14 September 2017, phone interview) concerning the Rainbow Labor campaign launch; Senator Janet Rice (24 November 2017, Parliament House, Canberra) concerning the Greens campaign. 
different State branches of the party. In Victoria (VIC) and Queensland (QLD), it is a formal network recognised in the party rules, while in Western Australia (WA) — where party branches are now divided between direct and local branches-it is one of the direct branches, along with the maritime and manufacturing branches and Perth Labor Women. In NSW, Rainbow Labor has no official status within the party but is included on membership forms. NSW Legislative Councillor Penny Sharpe was the driving force for the 2016 Rainbow Labor launch.

At the launch in Melbourne, on 21 May, Senator Wong reminded the LGBTI community that Labor would legislate for marriage equality within 100 days of gaining office, and unveiled a new commitment to the establishment of a dedicated LGBTI Discrimination Commissioner in the Human Rights Commission (Wong 2016a). The establishment of a dedicated Commissioner on 'Sexual Orientation, Gender Identity and Intersex Rights' had already been Greens policy (although not mentioned in their 'Equality for Everyone' election policy). While the Rainbow Labor launch attracted some media coverage on the ABC and Sky News (e.g. Beech 2016b; Hasham 2016), Labor's commitment on sexuality issues gained much more attention in the wake of Senator Wong's powerful Lionel Murphy Memorial Lecture on 21 June. What drew attention was the passion with which Wong connected Labor policy to her own personal experience and the potential of a plebiscite to make her own family, as well as the families of others, the target of condemnation and censure. She criticised those 'who don't understand that for gay and lesbian Australians hate speech is not abstract. It's real. It's part of our everyday life'. She said, 'I know that a plebiscite designed to deny me and many other Australians a marriage certificate will instead license hate speech to those who need little encouragement' (Wong 2016b).

Wong's statement that not one 'straight politician' advocating a plebiscite knew what it was like to live with casual and deliberate prejudice provoked a strong response from Treasurer Scott Morrison who claimed that he had also experienced hatred and bigotry for his views. The suggestion that opponents of marriage equality experienced hatred and bigotry similar to that experienced by the LGBTI community caused a social media frenzy and the hashtag \#scomophobia turned viral on Twitter and Facebook. Contributors pointed to the unlikelihood that a white Christian male from Sydney would be subject to the kind of bigotry experienced by, for example, an Asian migrant lesbian (Noyes 2016). 


\section{Gender equality policies}

The major parties have manifested considerable nervousness about producing women's policies in recent federal elections (see Table 28.6). Even when one has been produced, it has rarely been given a launch. For example, in 2007, the Coalition released its policy onto its website two days before the election, while in 2010 the Labor policy was slipped onto its website the day before the election.

Table 28.6. Women's policies at federal elections, 2007-16

\begin{tabular}{|l|l|l|}
\hline & Coalition & Labor Party \\
\hline 2007 & Yes & No \\
\hline 2010 & No & Yes \\
\hline 2013 & Yes & No \\
\hline 2016 & No & Yes \\
\hline
\end{tabular}

Source. Compiled by Marian Sawer. Originally published in Harris Rimmer and Sawer (2016).

In part, this can be attributed to the policy influence of neoliberalism and the narrowing of gender equality policy to a point where it is compatible with a market agenda (Kantola 2010). In countries where neoliberal influence has been greatest, parties of both centre-right and centre-left have switched the focus of their gender equality policy to the international arena, apart from the issue of gender-based violence. In the 2015 general election in the UK, for example, Rosie Campbell and Sarah Childs found evidence of a 'broad consensus' on issues of violence against women and girls, and promotion of gender equality internationally through development aid and in conflict zones (Campbell and Childs 2015: 211-12) This convergence on violence and the international arena does not mean all partisan differences disappear. In Australia and the UK, for example, there are important differences on issues such as how to address gender pay gaps (Campbell and Childs 2015: 215; Harris Rimmer and Sawer 2016).

However, this time Labor did launch a women's policy, thanks to the efforts of Shadow Minister for Women Senator Claire Moore, supported by the Caucus Status of Women Policy Committee. The latter has played an important role in keeping gender equality issues on the agenda for more than 30 years (Sawer and Turner 2016). As with the LGBTI policy launch, both institution-building and 'critical actors' within the 
party were crucial in engineering the policy events. The women's policy had detailed machinery commitments including an intergovernmental Ministerial Council on Gender Inequality; restoration of impact on women's statements for Cabinet proposals and gender budgeting; and reinstatement of the Australian Migrant and Refugee Women's Alliance as a funded peak advocacy group (Australian Labor Party (ALP) 2016). The policy also included significant commitments to front-line services dealing with domestic violence, including community legal centres and safe housing, commitments highlighted in the later campaign policy launch. The women's policy launch took the form of a 'family picnic' on 11 June, in the seat of Barton. The Shadow Minister and the Labor Leader's wife wore purple, while the Labor Leader wore a purple tie. In his speech, Shorten reaffirmed that 'equality for the women of Australia is a national priority' (Shorten 2016b).

In contrast to the Rainbow Labor campaign launch, however, there was practically no newspaper coverage of the women's policy launch. Proquest captured only three newspaper stories mentioning it: in the Advertiser, the Age and the Sydney Morning Herald, while the Daily Telegraph had earlier mentioned Labor's commitment to women's budget statements and gender parity in science, technology, engineering and mathematics (STEM) teaching scholarships (Bye and Meers 2016). There was somewhat more coverage on social media. A couple of substantial articles appeared on the Mamamia website, which has a unique audience of 899,000 according to the March 2016 Nielsen Digital Ratings. One of the Mamamia election articles compared Labor and Coalition policies on gender-based violence and included a photo from the Labor Women's Policy launch. It highlighted items such as Labor's commitment to five days of domestic violence leave and Minister for Women Michaelia Cash's opposition to such leave on the ground of the 'perverse disincentive' it would create for employers to hire women (Gagnon 2016). The other substantial article on Mamamia was a repost of an article by Eva Cox from The Conversation, again comparing party policy of particular interest to women. Cox was critical of the assumption of both major parties that the only way to achieve gender equality was to make women more competitive in paid employment, including through STEM funding (Cox 2016b).

As we have seen, Labor Leader Shorten has repeatedly emphasised the priority his government would give to gender equality. In contrast, while Prime Minister Turnbull had declared himself a feminist during the campaign, there was no purple policy launch for the Coalition, just 
a media release responding to Labor's Women's Policy and affirming 'the Turnbull Coalition's commitment to supporting Australian women' (LPA 2016). It included the STEM funding package also included later in the campaign policy launch.

Not only was there no Coalition women's policy (unlike the 2013 election where there was a significant machinery commitment) but the Coalition campaign launch was also disappointing. Turnbull spoke of the right to live without fear of violence and reminded listeners that his first announcement as prime minister had been funding to eliminate violence against women. What followed, however, was not a new funding commitment for women's refuges and front-line services; instead, it was funding to stop the 'trafficking of illegal firearms on our streets' (Turnbull 2016). As the Women's Electoral Lobby (WEL) commented, this was not of much use to women and children fleeing domestic violence (WEL 2016). WEL had been running a 'two cents a day' campaign, asking party leaders to commit to its Women and Children's Safety Program. According to its convenor, former head of the Office of the Status of Women Helen L'Orange, the campaign was largely ignored by the print media, although it did better on social media with some 160,000 hits and retweets. Another related campaign calling for an overhaul of the family court system was launched by former Australian of the Year Rosie Batty along with Women's Legal Services Australia. It was supported by more than 90 organisations and had the benefit of Batty's presence and personal story, but also failed to gain traction.

Women's advocacy organisations such as the National Foundation for Australian Women (NFAW) undertook the regular task of applying a gender lens to the policy offerings of political parties. NFAW presented comparisons of the available party policies of the Coalition, Labor and the Greens. On machinery of government, only Labor had commitments, while on Working Women's Centres both Labor and the Greens had commitments to specialised services, while the Coalition's commitment to competitive tendering meant that nonspecialised services might be selected (NFAW 2016). A newer advocacy organisation, Fair Agenda, sent a questionnaire to political parties and produced a scorecard based on responses. The Coalition did relatively poorly compared with the scores allocated to the Greens, the Nick Xenophon Team and the ALP-for example, on issues such as funding of family violence services, family law reform and paid parental leave (Fair Agenda 2016). The Nick Xenophon Team's commitment to Fair Agenda on paid parental leave, made on behalf 
of the party by successful Senate candidate Skye Kakoschke-Moore, was to be significant in determining the party's position on the issue after the election. The Work and Family Policy Roundtable (WFPR), made up of academic experts from 16 universities, also prepared a scorecard on policies, finding that neither Labor nor the Coalition had proposed an integrated approach to managing public policy on work and care, and that policy was going backwards-for example, the Coalition's policy on parental leave (WFPR 2016).

Pauline Hanson's One Nation did not respond to the Fair Agenda survey, but was notable for reviving an earlier commitment to the men's rights agenda - in particular, the abolition of the Family Court and its replacement by a Family Tribunal made up of 'people from mainstream Australia' (Pauline Hanson's One Nation 2016). This policy dated from the 1998 federal election when it was shared by parties such as Abolish Child Support/Family Court and the Family Law Reform Party. Hanson had declared that the 'white Anglo-Saxon male was the most downtrodden person in the country', something that appeared to contribute, along with her opposition to gun control, to the large gender gap in support for the party (Sawer 2000: 150-51).

\section{Conclusion}

Despite the feminist commitments of Liberal and Labor leaders in the 2016 election campaign, and the efforts of women's advocacy groups, gender equality policy in general failed to attract any significant attention. The one exception was the Coalition's deficit in terms of women candidates. Little attention was paid to the significant machinery of government and other policy commitments put forward by Labor and the Greens. In contrast, the issue of same-sex marriage continued to be a high profile one with a range of cross-cutting currents. There was strong opposition to the Coalition's proposed plebiscite by Senator Wong and LGBTI leaders inside and outside the ALP, but the new gay Coalition parliamentarians were more divided. 


\section{References}

Australian Broadcasting Corporation (ABC). 2016. 'Election 2016: Women and men split on idea of gender quotas in Parliament'. $A B C$ News, 23 June. Available at: www.abc.net.au/news/201606-23/election-gender-quotas-parliament-women-split-votecompass/7533006

Australian Labor Party (ALP). 2016. 'Australian women: Labor's positive policies', 11 June.

Beech, Alexandra. 2016a. 'Election 2016: Shorten defends "men rely on women" childcare comment'. $A B C$ News, 5 June. Available at: www. abc.net.au/news/2016-06-06/bill-shorten-stands-by-comments.../ 7481138

—_. 2016b. 'Election 2016: Labor plans to appoint discrimination commissioner to ensure LGBTI people "feel safer". $A B C$ News, 20 May. Available at: www.abc.net.au/news/2016-05-21/election2016-labor-promises-lgbti-discrimination-commissioner/7434660

Blumer, Clare. 2016. '7 things Vote Compass reveals about Australians' views on same-sex marriage'. $A B C$ News, 22 June. Available at: www.abc. net.au/news/2016-06-22/...vote-compass-same-sex-marriage/7520478

Bye, Clarissa and Daniel Meers. 2016. 'Leaders in uphill battle to woo all the single ladies'. Daily Telegraph, 21 May, p. 4.

Calilhanna, Ann-Marie. 2016. 'Labor will make marriage equality law'. Star Observer, photograph, 24 June.

Campbell, Rosie and Sarah Childs. 2015. 'All aboard the pink battle bus? Women voters, women's issues, candidates and party leaders'. Parliamentary Affairs 68: 206-23. doi.org/10.1093/pa/gsv036

Celis, Karen and Silvia Erzeel. 2015. 'Beyond the usual suspects: Nonleft, male and non-feminist MPs and the substantive representation of women'. Government and Opposition 50(1): 45-64. doi.org/10.1017/ gov.2013.42 
Cox, Eva. 2016a. 'The f-word enters the campaign and trips up both major parties'. The Conversation, 7 June. Available at: theconversation. $\mathrm{com} /$ the-f-word-enters-the-campaign-and-trips-up-both-majorparties-60617

- 2016b. 'Despite the rhetoric, this election fails the feminist test'. Mamamia, 29 June (Republished from The Conversation). Available at: www.mamamia.com.au/liberal-and-labor-parties/

Fair Agenda. 2016. 'Why should women vote for you?' Available at: www.fairagenda.org/scorecard

Gagnon, Alys. 2016. 'Everything you need to know about support for women experiencing family violence before you vote'. Mamamia, 11 June. Available at: www.mamamia.com.au/election-policydomestic-violence

Harris Rimmer, Susan and Marian Sawer. 2016. 'Neoliberalism and gender equality policy in Australia'. Australian Journal of Political Science 51(4): 742-58. doi.org/10.1080/10361146.2016.1222602

Hasham, Nicole. 2016. 'Labor pledges gay and lesbian rights watchdog if it wins office'. $A B C$ News, 21 May. Available at: www.smh.com.au/ federal-politics/federal-election-2016/labor-pledges-gay-and-lesbianrights-watchdog-if-it-wins-office-20160521-gp0h2t.html

Inter-Parliamentary Union (IPU). 2017. 'Women in national parliaments'. Available at: www.ipu.org/wmn-e/classif.htm

Kantola, Johanna. 2010. 'Shifting institutional and ideational terrains: The impact of Europeanisation and neoliberalism on women's policy agencies'. Policy \& Politics 38(3): 353-68. doi.org/10.1332/ $030557310 X 521053$

Karp, Paul. 2016. 'Record number of LGBTI candidates running in 2016 federal election'. Guardian, 28 June. Available at: www.theguardian. com/australia-news/2016/jun/28/record-number-of-lgbti-candidatesrunning-in-2016-federal-election?CMP=Share_iOSApp_Other

Kenny, Meryl and Tania Verge. 2013. 'Contagion theory revisited: When do political parties compete on women's representation?' Available at: www.aecpa.es/uploads/files/modules/congress/11/papers/636.pdf 
Knott, Matthew. 2016. 'Same-sex marriage: Malcolm Turnbull says MPs will have free vote regardless of plebiscite'. Sydney Morning Herald, 24 June. Available at: www.smh.com.au/federal-politics/federalelection-2016/samesex-marriage-malcolm-turnbull-says-mps-willhave-free-vote-regardless-of-plebiscite-20160624-gpqxxk.html

Koziol, Michael. 2016a. 'Election 2016: "That is prehistoric language": War of words over women's role in childcare'. Sydney Morning Herald, 6 June. Available at: www.smh.com.au/federal-politics/federal-election2016/election-2016-that-is-prehistoric-language-war-of-words-overwomens-role-in-childcare-20160606-gpcfiy.html

—_. 2016b. "It's an assault on every one of us": Malcolm Turnbull responds to Orlando shooting'. Sydney Morning Herald, 13 June. Available at: www.smh.com.au/federal-politics/federal-election-2016/ its-an-assault-on-every-one-of-us-malcolm-turnbull-responds-toorlando-shooting-20160612-gphjfg.html

Liberal Party of Australia (LPA). 2016. 'Turnbull Coalition's commitment to supporting Australian women'. Media release: 11 June. Available at: www.liberal.org.au/latest-news/2016/06/11/ turnbull-coalitions-commitment-supporting-australian-women

Matland, Richard E. and Donley T. Studlar. 1996. 'The contagion of women candidates in single-member district and proportional representation electoral systems: Canada and Norway'. Journal of Politics 58: 707-33. doi.org/10.2307/2960439

National Foundation for Australian Women (NFAW). 2016. 'What are they saying to Australian women? Election 2016: Policies and their impact on women'. Available at: www.nfaw.org/what-are-they-sayingto-women-election-2016/

Noyes, Jenny. 2016. 'The internet is having a field day with \#scomophobia after Scott Morrison claimed to be a victim of bigotry'. Daily Life, 22 June. Available at: www.dailylife.com.au/dl-people/dlentertainment/the-internet-is-having-a-field-day-with-scomophobiaafter-scott-morrison-claimed-to-be-a-victim-of-bigotry-20160622gppk $5 \mathrm{y} \cdot \mathrm{html}$

Pauline Hanson's One Nation. 2016. 'Policies'. Available at: www. onenation.com.au/policies 
Power, Shannon. 2016. 'How Bill Shorten became a champion of the LGBTI community'. Star Observer, 24 June. Available at: www. starobserver.com.au/news/how-bill-shorten-became-a-champion-ofthe-lgbti-community/150255

Reynolds, Emma and Debbie Schipp. 2016. 'Dinosaur, sexist or realist? Lisa Wilkinson tees off on Shorten'. Daily Telegraph, 6 June. Available at: www.dailytelegraph.com.au/entertainment/dinosaursexist-or-realist-lisa-wilkinson-tees-off-on-shorten/news-story/ede930 a9599fb7077d0ebbf95098b43f

Sawer, Marian. 2000. 'Women: Gender wars in the nineties'. In Marian Simms and John Warhurst (eds), Howard's Agenda: The 1998 Australian Election. St Lucia: University of Queensland Press, pp. 149-66.

Sawer, Marian and Alicia Turner. 2016. 'Specialised parliamentary bodies: Their role and relevance to women's movement repertoire'. Parliamentary Affairs 69(4): 763-77. doi.org/10.1093/pa/gsw003

Shorten, Bill. 2016a. 'Budget reply 2016'. 5 May. Available at: www.alp. org.au/bill_shorten_budget_reply_2016

— 2016b. 'Bill Shorten's speech launching Labor's gender equality policy'. Labor Herald, 11 June. Available at: www.billshorten.com. au/launch_of_labor_s_gender_equality_policy_sydney_saturday_11_ june_2016

Smith, Lydia. 2015. 'Election 2015: Which parties score best on LGBT rights?' International Business Times, 5 May. Available at: www.ibtimes. co.uk/election-2015-which-parties-score-best-lgbt-rights-1499774

Troeth, Judith. 2010. 'Modernising the parliamentary Liberal Party by adopting the organisational wing's quota system for preselections'. Discussion paper. Analysis and Policy Observatory. Available at: www. apo.org.au/node/57011

Turnbull, Malcolm. 2016. 'Malcolm Turnbull Launches Liberal Party Election Campaign', 26 June. (Original title: 'Transcript of Prime Minister Malcolm Turnbull's speech at the Liberal Party's election campaign launch in Sydney'). Available at: www.australianpolitics. com/2016/06/26/turnbull-launches-liberal-campaign.html 
Women's Electoral Lobby (WEL). 2016. 'Lies and broken promises'. Email to membership from wel@welnsw.org.au, 27 June.

Wong, Penny. 2016a. 'Rainbow Labor National Day of Action and Campaign Launch, Melbourne'. Speech: 21 May. Available at: www. pennywong.com.au/speeches/rainbow-labor-national-day-of-actionand-campaign-launch-melbourne/

__ 2016b. '28th Annual Lionel Murphy Memorial Lecture. Australian National University, Canberra'. Speech: 21 June. Available at: www. pennywong.com.au/speeches/28th-annual-lionel-murphy-memoriallecture-australian-national-university-canberra/

Work and Family Policy Roundtable (WFPR). 2016. The Work and Family Policy Roundtable Election Evaluation, June 2016. Available at: www. workandfamilypolicyroundtable.org/wp-content/uploads/2016/06/ Benchmark-2016-scorecard.pdf

Workplace Gender Equality Agency (WGEA). 2016. 'Gender pay gap statistics'. WGEA. Available at: www.wgea.gov.au/sites/default/files/ Gender_Pay_Gap_Factsheet.pdf 
This text is taken from Double Disillusion: The 2016 Australian Federal Election, edited by Anika Gauja, Peter Chen, Jennifer Curtin and Juliet Pietsch, published 2018 by ANU Press, The Australian

National University, Canberra, Australia.

doi.org/10.22459/DD.04.2018.28 